\title{
Pengembangan bahan ajar cerita rakyat di SD Xaverius Lubuklinggau
}

\author{
Inda Puspita Sari ${ }^{1 *}$, Juwati ${ }^{b, 2}$ \\ Pendidikan Bahasa dan Sastra Indonesia, STKIP PGRI, Lubuklinggau \\ 1 indashop2I@gmail.com*; ${ }^{2}$ watiaja56@ymail.com; \\ *korespondensi penulis
}

\begin{tabular}{ll}
\hline Informasi artikel & \\
\hline Sejarah artikel: & \\
Diterima & $: 6$ Desember 2018 \\
Revisi & $: 9$ April 2019 \\
Dipublikasikan & $: 25$ April 2019 \\
\hline
\end{tabular}

Kata kunci:

Bahan ajar

Cerita rakyat

Pengembangan \begin{abstract}
ABSTRAK
Tujuan dalam penelitian ini adalah mengembangkan produk bahan ajar bersumber pada cerita rakyat untuk siswa kelas V SD. Sementara metode yang digunakan dalam penelitian ini adalah Research and Development (R\&D). Adapun hasil penelitian pengembangan dalam penelitian ini adalah pertama, siswa dan guru memiliki kebutuhan yang sama yaitu bahan ajar bersumber pada cerita rakyat yang dapat dijadikan pendamping bahan ajar yang selama ini digunakan di sekolah. Kedua, prototipe bahan ajar cerita rakyat memiliki spesifikasi cover, kata pengantar, daftar isi, petunjuk belajar, $\mathrm{SK} / \mathrm{KD} /$ indikator/tujuan, materi, latihan, rangkuman, evaluasi, penilaian, latihan akhir, dan daftar pustaka, biodata penulis. Ketiga, hasil validasi dinyatakan baik atau layak digunakan di SD Xaverius Lubuklinggau. Hal ini didasarkan pada hasil validasi ahli yang dilakukan pada empat aspek, yaitu kelayakan isi atau materi, kelayakan bahasa, kelayakan penyajikan dan kegrafikaan. Keempat, uji efektivitas produk bahan ajar membuktikan hasil $U_{j i-} T$ terhadap bahan ajar sangat signifikan. Hal ini dapat dilihat sekolah yang dijadikan sampel dalam penelitian diperoleh hasil Asymp.sig. (2-teiled) lebih besar dari pada taraf signifikan 0,05.
\end{abstract}

\section{Key word:}

Teaching materials

Folklore

Development

\begin{abstract}
The purpose of this research is to develop teaching material products sourced from folklore for fifth grade elementary school students. While the method used in this study is Research and Development ( $\&$ D). The results of development research in this study are first, students and teachers have the same needs, namely teaching materials sourced from folklore that can be used as a companion teaching materials that have been used in school. Secondly, prototypes of folklore teaching materials have cover specifications, introductory words, table of contents, learning instructions, $\mathrm{SK} / \mathrm{KD} /$ indicators/goals, material, training, summary, evaluation, assessment, final training, and bibliography, biodata of the author. Third, the validation results are stated as good or feasible to be used in Xaverius Lubuklinggau Elementary School. This is based on the results of expert validation carried out on four aspects, namely the feasibility of content or material, the feasibility of language, the feasibility of the presenter and graphics. Fourth, the effectiveness test of teaching material products proves that the results of the $T$ Test on teaching materials are very significant. This can be seen by the schools that were sampled in the study obtained by the results of Asymp.ig. (2-teiled) greater than the significant level of 0.05 .
\end{abstract}

\section{Copyright (C) 2019 Universitas Ahmad Dahlan}

\section{Pendahuluan}

Cerita rakyat atau folklor merupakan bagian dari suatu kebudayaan yang tumbuh dan berkembang di tengah-tengah masyarakat dan diwariskan secara turun temurun secara lisan sebagai milik bersama. Sastra lisan merupakan pencerminan situasi, kondisi, dan tata krama masyarakat pendukungnya. Menurut Danandjaja (2002) folklor merupakan sebagian dari kebudayaan suatu kolektif yang tersebar dan diwariskan secara turun temurun di antara kolektif macam apa saja secara tradisional dalam versi yang berbeda-beda, baik dalam bentuk lisan maupun disertai contoh dengan gerak isyarat atau alat bantu. Folklor memiliki kedudukan yang sangat penting di tengah masyarakat. Hal ini dikarenakan cerita rakyat dapat menjadi wahana pembelajaran kita untuk memahami masyarakat dan budayanya. Jelas terlihat 
bahwa folklor tidak akan pernah bisa dilepaskan dari konteks kebudayaan.

Lantas bagaimanakah melestarikan folklor atau cerita rakyat Lubuklinggau? Salah satu wujud pelestarian dan pengembangan sastra lisan khususnya cerita rakyat Lubuklinggau adalah dengan menjadikannya sebagai materi pembelajaran sastra di sekolah. Salah satunya dapat dituangkan ke dalam bahan ajar cerita rakyat Lubuklinggau dan sekitarnya yang memuat nilai-nilai moral yang dapat dijadikan sebagai sarana penyampaian nilai-nilai pendidikan karakter.

Abidin (2013) mengemukakan bahwa bahan ajar sastra adalah bahan ajar yang paling tepat digunakan sebagai saluran pendidikan karakter. Ia berpendapat bahwa karya sastra memiliki nilai-nilai yang dapat digunakan untuk membentuk budi pekerti siswa. Melalui karya sastra, siswa dapat menemukan karakter-karakter yang baik untuk diteladani dan diterapkan dalam kehidupan seharihari, baik dalam keluarga, sekolah, maupun masyarakat. Nilai-nilai pendidikan karakter tersebut seperti, kejujuran, kebaikan, persahabatan, persaudaraan, kekeluargaan, keikhlasan, ketulusan, kebersamaan, dan nilai-nilai karakter lainnya.

Namun, pada kenyataannya tujuan pembelajaran sastra berbasis cerita rakyat di SD Lubuklinggau belum mencapai sasaran yang diharapkan. Hal ini disebabkan beberapa faktor antara lain, belum adanya bahan ajar berbasis cerita rakyat Lubuklinggau dan sekitarnya dalam pembelajaran sastra. Kemudian, minimnya literatur yang berkaitan dengan sastra daerah, dan minimnya penguasaan siswa terhadap bahasa daerah. Padahal diketahui bahwa melalui sastra siswa akan mendapatkan nilai-nilai positif yang sangat berarti untuk menunjang perkembangannya. Selain itu melalui sastra daerah yaitu cerita rakyat dapat mendidik siswa menanamkan nilai-nilai karakter.

Berdasarkan hasil analisis kebutuhan, bahan ajar yang digunakan selama ini dalam proses belajar mengajar guru menggunakan bahan ajar yang sudah tersedia yaitu buku sekolah elektronik sebagai sumber pembelajaran tanpa ada upaya untuk merencanakan, menyiapkan, serta menyusun sendiri bahan ajar. Padahal diketahui bahwa bahan ajar yang tersedia kurang memberikan pemahaman terkait cerita rakyat Lubuklinggau, Musi Rawas Sumatera Selatan. Cerita rakyat yang terdapat dalam bahan ajar yang selama digunakan adalah cerita rakyat yang berasal dari luar Lubuklinggau, Musi Rawas Sumatera Selatan. Fakta tersebut sejalan dengan pendapat Prastowo (20II) bahwa banyak pendidik yang masih menggunakan bahan ajar konvensional, yaitu bahan ajar tinggal pakai dan tinggal beli tanpa ada upaya menyusun sendiri. Dengan demikian, sangat memungkinkan jika bahan ajar yang digunakan tidak kontekstual, tidak menarik, monoton dan tidak sesuai dengan kebutuhan siswa.

Sebagai seorang pendidik, peneliti bermaksud mengembangkan bahan ajar bersumber pada cerita rakyat yang diharapkan dapat melibatkan siswa secara aktif dan konstruktif dalam pembelajaran sastra. Depdiknas (2008) mengatakan bahwa guru perlu mengembangkan bahan ajar sendiri dengan alasan ketersediaan bahan sesuai dengan kurikulum, karakteristik sasaran, dan tuntutan pemecahan masalah. Pernyataan tersebut dipertegas Arifin dan Kusrianto (2009) bahwa sangat disayangkan jika seorang guru yang selama kariernya tidak pernah membuat bahan ajar sendiri.

Penelitian ini didasari belum dikembangkannya bahan ajar sastra khususnya cerita rakyat Lubuklinggau dan sekitarnya yang diyakini mempunyai nilai lebih dari sekedar bacaan penghibur saja tetapi padat dengan nilai-nilai moral yang dapat menanamkan nilai-nilai karakter. Berdasarkan pertimbangan tersebut, maka perlu disusun dan dikembangkan bahan ajar bersumber pada cerita rakyat Lubuklinggau agar terdapat bahan ajar yang kontekstual yang dekat dengan siswa.

Dengan adanya bahan ajar cerita rakyat Lubuklinggau dalam pembelajaran sastra diharapkan siswa tidak kehilangan jati diri serta nilai-nilai budaya suatu suku bangsa yang bisa menjadi teladan untuk generasi berikutnya. Untuk itu siswa perlu dibekali pengetahuan yang mendalam tentang sastra daerah Lubuklinggau yang terdokumentasi dalam bahan ajar cerita rakyat

\section{Metode}

Metode yang digunakan dalam penelitian ini adalah penelitian dan pengembangan (Research and Development) atau lebih dikenal dengan sebutan $\mathrm{R}$ and D. Penelitian dan pengembangan menurut Borg dan Gall (I983) adalah "a process used to develop and validate educational products" (penelitian dan pengembangan merupakan proses untuk mengembangkan dan memvalidasi produk pendidikan).

Sementara langkah-langkah pengembangan bahan ajar cerita rakyat Lubuklinggau dalam pembelajaran sastra sebagai alternatif menanamkan nilai-nilai karakter siswa SD di Kota Lubuklinggau menggunakan langkah-langkah menurut Borg dan Gall yang terdiri dari IO langkah. Kesepuluh langkah dapat dituliskan pada tabel I. 
Tabel I Langkah-langkah penelitian pengembangan

\begin{tabular}{|c|c|}
\hline Langkah Utama & I0 langkah Borg dan Gall \\
\hline $\begin{array}{l}\text { Penelitian dan } \\
\text { Pengumpulan } \\
\text { Informasi }\end{array}$ & $\begin{array}{l}\text { I. Penelitian dan Pengumpulan } \\
\text { Informasi }\end{array}$ \\
\hline Perencanaan & 2. Perencanaan \\
\hline $\begin{array}{l}\text { Pengembangan Produk } \\
\text { Awal }\end{array}$ & 3. Pengembangan Produk Awal \\
\hline $\begin{array}{l}\text { Uji Lapangan dan } \\
\text { Revisi Produk }\end{array}$ & $\begin{array}{l}\text { 4. Uji lapangan awal } \\
\text { 5. Revisi produk utama } \\
\text { 6. Uji lapangan uji utama } \\
\text { 7. Revisi produk } \\
\text { 8. Uji lapangan } \\
\text { 8. Uji lapangan }\end{array}$ \\
\hline Revisi Produk Akhir & 9. Revisi produk akhir \\
\hline $\begin{array}{l}\text { Diseminasi dan } \\
\text { Implementasi }\end{array}$ & I0. Diseminasi dan implementasi \\
\hline
\end{tabular}

Berdasarkan langkah-langkah pada tabel I, penelitian ini berskala kecil, yaitu pengembangan bahan ajar cerita rakyat dalam pembelajaran sastra sebagai alternatif menanamkan nilai-nilai karakter siswa SD di Kota Lubuklinggau. Borg dan Gall menyarankan membatasi penelitian pada skala kecil pula untuk membatasi langkah penelitian. Oleh karena itu, penelitian ini dibatasi sampai dengan uji lapangan operasional, yaitu dihasilkannya prototipe bahan ajar cerita rakyat dalam pembelajaran sastra sebagai alternatif menanamkan nilai-nilai karakter siswa SD di Kota Lubuklinggau. Diseminasi dan implementasi produk akhir hasil penelitian akan dilakukan jika kelak ada yang bersedia menerbitkannya.

\section{Hasil dan pembahasan}

\section{Hasil Analisis Kebutuhan}

Berdasarkan analisis kebutuhan siswa dan guru yang mengajar Bahasa Indonesia terhadap bahan ajar bersumber cerita rakyat Lubuklinggau, Musi Rawas, Sumatera Selatan hasilnya menunjukkan adanya kebutuhan yang sama. Jawaban angket tersebut menunjukkan guru bahasa Indonesia di kelas V SD senang memberikan pembelajaran sastra. Menurutnya, memberikan materi pembelajaran sastra akan menambah wawasan siswa, melatih kebiasaan siswa untuk berpikir, menumbuhkan rasa cinta terhadap karya sastra yang salah satunya cerita rakyat Lubuklinggau, Musi Rawas, Sumatera Selatan, memberanikan siswa untuk belajar mengungkapkan apa yang dirasakan dan apa yang dilihat di sekelilingnya, serta dapat dijadikan sebagai hiburan.

Berdasarkan jawaban angket sebesar 100\% bahwa guru bahasa Indonesia yang mengajar di kelas $\mathrm{V}$ sangat memerlukan bahan ajar bersumber dari cerita rakyat yang ada di Lubuklinggau, Musi Rawas Sumatera Selatan. Tujuannya, agar siswa dapat dengan mudah mengenal, memahami makna cerita rakyat yang ada di daerah tempat tinggalnya. Selain itu, bahan ajar bersumber cerita rakyat Lubuklinggau diharapkan dapat melestarikan nilai-nilai luhur yang terdapat dalam cerita rakyat tersebut sekaligus sebagai pendidikan karakter.

Terkait tema yang dapat diberikan pada siswa sesuai dengan tuntutan kurikulum Sekolah Dasar antara lain meliputi: tema sosial, kepatuhan, perilaku jujur, tanggung jawab, kesantunan. Guru bahkan menyatakan bahwa tema-tema tersebut merupakan tema yang tepat untuk diberikan kepada siswa Sekolah Dasar melalui pembelajaran sastra. Melalui cerita rakyat tersebut guru dapat memberikan contoh tokoh-tokoh yang dapat diteladani siswa guna menanamkan karakter anak yang gagah berani, suka menolong, hormat kepada orang tua, sayang kepada saudara, dan mulia budi pekertinya, misalnya yang terdapat dalam cerita rakyat "Muncar Salangit".

Bagi guru cerita rakyat merupakan kekayaan daerah, oleh karena itu sastra daerah perlu dipertahankan dan diajarkan kepada para siswa karena materi tersebut sangat dibutuhkan di Lubuklinggau khususnya bagi siswa Sekolah Dasar. Namun Tanpa adanya dukungan dari masyarakat, cerita rakyat bercorak daerah akan hilang dan masyarakat akan kehilangan ciri budaya daerahnya oleh karena itu cerita rakyat asal Lubuklinggau, Musi Rawas Sumatera Selatan perlu dipertahankan. Dengan membaca sastra daerah pembaca dapat mengetahui asal-usul suatu daerah, misalnya legenda "Moneng Sepati" yang mengisahkan terjadinya daerah Taba Pingin. Cerita rakyat yang berbentuk dongeng, legenda, dan mite hanya didengar sebelum anak memasuki jenjang pendidikan formal, setelah itu cerita rakyat tidak diperoleh lagi dalam lingkungan keluarga maupun sekolah.

Persentase jawaban guru yang menyatakan bahwa cerita rakyat yang terdapat di Lubuklinggau, Musi Rawas Sumatera Selatan yaitu dongeng, legenda, dan mite sangat dibutuhkan sebesar 8,75\%. Berdasarkan persentase tersebut $\mathrm{di}$ atas, tampak bahwa materi sastra bermuatan kearifan lokal yang ada di Lubuklinggau memang benar-benar dibutuhkan oleh siswa Sekolah Dasar di Lubuklinggau.

Berkaitan dengan sumber bahan ajar yang digunakan dalam pembelajaran sastra yaitu cerita rakyat di kelas, guru tersebut menggunakan buku paket yang diterbitkan Kemendikbud serta buku penunjang lainnya. Dari jawaban angket menunjukkan bahwa buku yang digunakan memiliki keunggulan. Keunggulan buku tersebut materi sesuai 
dengan standar kompetensi dan kompetensi dasar. Meskipun bahan ajar yang digunakan di kelas memiliki keunggulan, namun bahan ajar tersebut juga memiliki kelemahan. Kelemahan bahan ajar yang selama ini digunakan di antaranya kajian teori yang disajikan kurang lengkap, kurang terperinci, dan cerita rakyat yang ada dalam buku yang selama ini digunakan berasal dari luar Lubuklinggau. Dengan demikian, bahan ajar yang selama ini digunakan tidak kontekstual sesuai dengan kondisi lingkungan siswa.

Sementara dari angket tampak siswa memberikan dukungan yang serius terhadap pembelajaran sastra yaitu cerita rakyat Lubuklinggau. Hal ini tampak dari jawaban angket sebesar $80 \%$ cerita rakyat sangat dibutuhkan untuk mengenalkan nilai-nilai budaya yang ada di Lubuklinggau dengan alasan siswa lebih mengenal cerita-cerita di luar daerahnya sendiri.

Kemudian dari pembelajaran sastra siswa menyadari bahwa membaca sastra yaitu cerita rakyat sangat besar pengaruhnya terhadap pemahaman nilai-nilai budaya. Sebab, dengan membaca cerita rakyat maka dapat mengetahui asal usul suatu daerah dan sebagainya seperti cerita rakyat yang berjudul Moneng Sepati, Batu Urip, dan lain-lain. Persentase jawaban yang mendukung pernyataan tersebut sebesar $80 \%$.

Namun, siswa mengalami kesulitan untuk mendapatkan buku cerita-cerita rakyat daerah sendiri yang ada di perpustakaan sekolah. Hal ini tampak dari jawaban siswa 95\% tidak terdapat cerita rakyat Lubuklinggau, Musi Rawas Sumatera Selatan. Selanjutnya bahan ajar yang dijadikan buku pegangan tidak lengkap dan minimnya sumber literatur. Hal ini tampak pada persentase sebesar $97,5 \%$ jawaban siswa yang mengatakan cerita-cerita yang ada dalam buku paket yaitu cerita yang ada di luar Lubuklinggau seperti Maling Kundang, Takupan Perahu, dan lain-lain.

Ketergantungan guru bahasa Indonesia terhadap materi sastra daerah yang terdapat pada buku paket Bahasa Indonesia Kelas $\mathrm{V}$ sangat tinggi. Guru cenderung mengajarkan materi sastra yang terdapat pada buku paket, tanpa ada usaha mengajarkan cerita-cerita rakyat dari Lubuklinggau. Dengan alasan bahwa di perpustakaan sekolah tidak ada cerita rakyat Lubuklinggau, Musi Rawas Sumatera Selatan. Akibatnya pembelajaran sastra yaitu cerita rakyat yang berasal dari Lubuklinggau tidak tersentuh dalam pembelajaran bahasa Indonesia. $\mathrm{Hal}$ ini tampak dari jawaban siswa terhadap angket yang diberikan yaitu $100 \%$ para siswa belum pernah mendapat materi yang berkaitan tentang sastra lama asal Lubuklinggau dalam pembelajaran Bahasa
Indonesia, namun pengertiannya sudah diajarkan tetapi tidak secara mendetail atau menyeluruh.

Minimnya buku bacaan cerita rakyat yang ada di Lubuklinggau berdampak pada penyampaian materi sastra yang kurang memuaskan. Hal ini dilihat di perpustakaan sekolah tidak ada buku tentang cerita-cerita rakyat Lubuklinggau yang ada hanya cerita-cerita yang ada di luar daerah Lubuklingau. Guru selama ini beranggapan cerita daerah yang disampaikan cukup yang terdapat pada buku paket, sehingga materi sastra yaitu cerita rakyat dari Lubuklinggau, Musi Rawas Sumatera Selatan hampir tidak tersentuh dalam pembelajaran bahasa Indonesia.

Pengetahuan siswa terhadap sastra berupa dongeng, legenda, dan mite yang ada di Lubuklinggau sangat minim. Dengan demikian, harapan siswa ingin mengenal cerita rakyat yang dikemas dalam bentuk bahan ajar bersumber dari cerita rakyat Lubuklinggau, Musi rawas Sumatera Selatan yang didalamnya membahasa tentang ceritacerita rakyat yang dapat diketahui nilai-nilai budaya guna membentuk karakter siswa sejak dini usia SD. Hal ini dapat dibuktikan dengan jawaban angket sebesar 95\% menjawab sastra rakyat dari Lubuklinggau, Musi Rawas Sumatera Selatan sangat dibutuhkan siswa.

\section{Rancangan Bahan Ajar yang Dikembangkan}

Berdasarkan analisis kebutuhan yang telah dilakukan peneliti, selanjutnya peneliti merancang prototipe bahan ajar berdasarkan keinginankeinginan guru dan siswa kelas V SD Kota Lubuklinggau. Pertama-tama yang harus peneliti lakukan untuk merancang prototipe bahan ajar adalah dengan melakukan realisasi kontekstual dan realisasi pedagogik. Pada tahap kontekstual, peneliti melakukan analisis tujuan pembelajaran yang akan dicapai. Hasilnya, peneliti mengembangkan tujuan pembelajaran menemukan nilai-nilai luhur yang dapat membentuk karakter siswa yang terdapat dalam cerita rakyat Lubuklinggau, Musi Rawas Sumatera Selatan. Selanjutnya, untuk merealisasikan soal evaluasi yang kontekstual peneliti melakukan tes menemukan nilai-nilai apa saja yang terdapat dalam cerita rakyat Lubuklinggau, tokoh yang dapat diteladani dalam kehidupan sehari-hari dan lain-lain.

Tahap selanjutnya adalah realisasi pedagogik yang diwujudkan dengan penyusunan petunjuk belajar, materi, latihan, evaluasi yang disajikan dalam bahan ajar hasil pengembangan. Selain itu, siswa juga diberi latihan menemukan nilai-nilai yang dapat diteladani dari tokoh yang menjadi idolanya, menemukan nilai-nilai budaya yang sampai sekarang 
masih tertanam bagi masyarakat Lubuklinggau, Musi Rawas Sumatera Selatan.

Setelah tahap realisasi kontekstual dan pedagogik, tahap selanjutnya adalah produk bahan ajar. Bahan ajar yang dihasilkan yaitu bahan ajar bersumber dari cerita rakyat Lubuklinggau, Musi Rawas Sumatera Selatan dalam pembelajaran sastra yang digunakan sebagai pendamping buku yang digunakan di sekolah. Sebelum bahan ajar diujicobakan di sekolah secara terbatas, bahan ajar dilakukan penilaian terlebih dahulu oleh pakar atau ahli di bidangnya. Ahli materi untuk menilai kebenaran materi, ahli bahasa yang menilai bahasa dan kejelasan informasi, ahli penyajian dan ahli kegrafikaan menilai kejelasan tujuan, urutan penyajian, dan pemberian motivasi, serta aspek-aspek kegrafikaan.

\section{Hasil Validasi Ahli Bahan Ajar yang Dikembangkan}

Setelah menghasilkan prototipe bahan ajar bersumber dari cerita rakyat Lubuklinggau, Musi Rawas Sumatera Selatan, langkah selanjutnya adalah validasi. Validasi terhadap bahan ajar bersumber dari cerita rakyat Lubuklinggau Musi rawas, Sumatera Selatan tersebut meliputi (I) kelayakan isi, (2) kelayakan bahasa, (3) kelayakan penyajian dan kegrafikaan. Sementara pakar atau ahli yang menilai bahan ajar cerita rakyat ialah Dr. Y. Satinem, M.Pd. (Dosen STKIP-PGRI Lubuklinggau) yang menilai aspek kelayakan isi/materi, Dodik Mulyono, M.Pd. (Dosen STKIP-PGRI Lubuklinggau) menilai aspek kelayakan kegrafikaan dan penyajian, dan Narulita, S.Pd. (Guru) menilai aspek kebahasaan.

Berdasarkan hasil penilaian, komponen kelayakan isi dapat dikategorikan sangat baik. Secara keseluruhan dari skor maksimal 35, komponen kelayakan isi memperoleh skor 30. Kemudian, hasil penilaian terhadap komponen penyajian dan kegrafikaan secara keseluruhan komponen penyajian dan kegrafikaan dari skor maksimal 45, memperoleh skor 32. Artinya, komponen penyajian dan kegrafikaan bahan ajar yang dikembangkan termasuk kategori baik. Penilaian aspek kebahasaan dapat dikategorikan sangat baik yaitu I8 dari skor maksimal 20

\section{Uji Efektivitas Bahan Ajar yang Dikembangkan}

Untuk mengetahui efektivitas bahan ajar bersumber dari cerita rakyat Lubuklinggau, Musi Rawas Sumatera Selatan, dilakukan penelitian melalui uji coba dua kali pokok bahasan. Kedua pokok bahasan bersumber pada cerita I) Batu Tangkup; 2) Silampari. Uji efektivitas dilakukan di SD Xaverius Lubuklinggau.

Untuk mengetahui efektivitas pembelajaran sastra yaitu cerita rakyat yang terdapat dalam bahan ajar hasil pengembangan dilakukan analisis statistik.
Analisis statistik menggunakan Uji-T satu arah dengan SPSS. Analisis statistik bertujuan untuk menguji hipotesis yang menyatakan bahwa nilai ratarata ketuntusan belajar siswa untuk kelas tinggi yaitu SD Xaverius sebesar 75. Berikut ini hasil nilai penghitungan statistik dengan menggunakan SPSS.

a. Test distribution is Normal.

Hasil SPSS menunjukkan bahwa data berdistribusi normal, ditunjukkan dengan nilai Asymp.sig. (2-teiled) I,87 pada signifikan level 0,05. Berikut dijelaskan pula ketuntasan hasil belajar siswa kelas $\mathrm{V}$ dengan menggunakan bahan ajar hasil pengembangan peneliti.

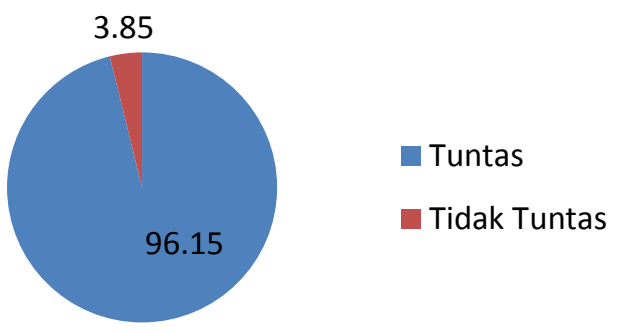

Gambar I. Ketuntasan hasil belajar

Gambar I menunjukkan ketuntasan belajar siswa kelas V SD Xaverius Lubuklinggau dengan menggunakan bahan ajar hasil pengembangan yaitu bahan ajar bersumber cerita rakyat Lubuklinggau, Musi Rawas Sumatera Selatan. Adapun besarnya KKM bahasa Indonesia untuk siswa kelas V SD Xaverius 75. Dengan demikian, peneliti menarik simpulan bahwa penelitian dapat diakhiri pada pertemuan kedua karena 96,15\% siswa telah mencapai KKM yang ditentukan dan hanya 3,85\% siswa belum mencapai KKM yang ditentukan.

Penelitian $R \& D$ terdahulu yang dilakukan oleh Satinem dan Juwati (2017) diketahui bahwa From the data obtained information about the highest score on the pretest was 85 the highest value and the lowest value was 40, whereas in posttest, the highest value was 95 and the lowest value was 60 . That is, there was an increase in the ability of students after using the results of the development of teaching materials (Dari data yang diperoleh skor tertinggi pada pretest adalah 85 dan nilai terendah adalah 40,sedangkan pada posttest, nilai tertinggi adalah 95 dan nilai terendah adalah 60. Artinya, ada peningkatan kemampuan siswa setelah menggunakan bahan ajar hasil pengembangan).

Penelitian selanjutnya juga telah dilaksanakan Satinem dan Juwati (2018) menghasilkan bahwa The average value of learning completeness after using writing materials is the same or greater with the Minimal Completeness Criteria (KKM) in each school, meaning that the teaching materials is 
effective used to improve the students' ability in writing poetry (Berdasarkan hasil uji dari tiga sekolah, dapat disimpulkan bahwa t-hitung > t-tabel, sehingga $\mathrm{HO}$ ditolak, dan $\mathrm{Ha}$ diterima. nilai rata-rata kelengkapan pembelajaran setelah menggunakan bahan ajar adalah sama atau lebih besar dengan Kriteria Ketuntasan Minimal (KKM) di masingmasing sekolah, artinya bahan ajar efektif digunakan untuk meningkatkan kemampuan siswa dalam menulis puisi).

Berdasarkan hasil penelitian yang telah peneliti lakukan dengan penelitian terdahulu didapat persamaan bahwa bahan ajar hasil pengembangan sama-sama menunjukkan adanya peningkatan kemampuan siswa setelah menggunakan bahan ajar hasil pengembangan.

\section{Simpulan}

Berdasarkan hasil penelitian dan pembahasan yang dikemukakan dalam bab sebelumnya dapat ditarik beberapa simpulan.

Pertama, siswa dan guru memiliki kebutuhan yang sama yaitu bahan ajar bersumber pada cerita rakyat yang dapat dijadikan pendamping bahan ajar yang selama ini digunakan di sekolah.

Kedua, bahan ajar cerita rakyat memiliki spesifikasi bagian pendahuluan, bagian isi, dan bagian penutup. Bagian pendahuluan mencakup cover, kata pengantar, daftar isi, petunjuk belajar. Bagian isi mencakup SK/KD/indikator/tujuan, materi, latihan, rangkuman, evaluasi, penilaian, latihan akhir, dan daftar pustaka. Sementara bagian penutup mencakup biodata penulis.

Ketiga, bahan ajar bersumber pada cerita rakyat dapat dinyatakan baik atau layak digunakan di SD Xaverius Lubuklinggau. Hal ini didasarkan pada hasil validasi ahli yang dilakukan pada empat aspek, yaitu kelayakan isi atau materi, kelayakan bahasa, kelayakan penyajian dan kegrafikaan.

Keempat, hasil uji efektivitas produk bahan ajar yang dilakukan peneliti membuktikan bahwa hasil Uji-T terhadap bahan ajar yang dikembangkan sangat signifikan. Hal ini dapat dilihat dari tiga sekolah yang dijadikan sampel dalam penelitian diperoleh hasil Asymp.sig. (2-teiled) lebih besar dari pada taraf signifikan 0,05 .

\section{Persantunan}

Artikel ini pengembangan dari penelitian hibah Kemenristekdikti yang berjudul "Bahan Ajar Cerita Rakyat Lubuklinggau dalam Pembelajaran Sastra
Sebagai Alternatif Menanamkan Pendidikan Karakter (Penelitian Pengembangan Di Sd Kota Lubuklinggau). Ucapan terima kasih kepada Direktorat Riset dan Pengabdian Masyarakat, Direktorat Jenderal Penguatan Riset dan Pengembangan Kementerian Riset, Teknologi dan Pendidikan Tinggi Sesuai dengan Kontrak Penelitian Tahun Anggaran 2018 Nomor: Nomor:2I50/SP2H/PPM/K2/KM/2018.

Selanjutnya ucapan terima kasih disampaikan kepada reviewer yang telah membaca, mengoreksi, dan memberi masukan terhadap artikel penelitian ini.

\section{Daftar Pustaka}

Abidin, Yunus. (2013). Pembelajaran Bahasa Berbasis Pendidikan Karakter. Bandung: PT Refika Aditama.

Arifin, Syamsul dan Adi Kusrianto. (2009). Sukses Menulis Buku Ajar dan Referensi. Jakarta: Grasindo.

Borg and Gall. (1983). Educational Research: An Introduction . London: Logman.

Danandjaja, James. 2002. Folklor Indonesia, Ilmu Gosip, Dongeng dan Lain-lain. Jakarta: Temprit.

Depdiknas. (2008). Panduan Pemgembangan Bahan Ajar. Jakarta: Dirjen Manajemen Pendidikan Dasar dan Menengah.

Lestari, Ika. (2013). Pengembangan Bahan Ajar Berbasis Kompetensi: Sesuai dengan Kurikulum Tingkat Satuan pendidikan. Padang: Akademia Permata.

Pannen, Paulina dan Purwanto. (200I). Penulisan Bahan Ajar: Jakarta: Pusat Antar Universitas untuk Peningkatan dan Pengembangan Aktivitas Instruksional Ditjen Dikti Diknas.

Prastowo. (2011). Panduan Kreatif Membuat Bahan Ajar Inovatif. Jakarta: Diva Press.

Suwandi, Syam. (1986). Kehidupan Masyarakat, Upacara Adat, Sejarah dan Legenda Daerah Musirawas. Lubuklinggau.

Satinem dan Juwati. (2017). Designing Writing Material of Short Story through Show Not Tell Model at SMA Xaverius Lubuklinggau. Journal of Indonesian Language Education and Literary. 2(I).I3-22.

http://usnsj.com/index.php/JILEL/article/vi ew/2.I.I3-22

Satinem, \& Juwati. (2018). Development of Teaching Materials of Poetry Writing Using Pictures for the Elementary Students. Advances in Language and Literary Studies, 9(3), I. doi:I0.7575/aiac.alls.v.9n.3p.I 